\title{
REPARATIVE OSTEOGENESIS IN NORMAL STATE AND UNDER CONDITIONS OF IODINE DEFICIENCY
}

\author{
Kovalchuk P. Ye., PhD in Traumatology, Assoc. Professor, Department of Traumatology and \\ Orthopedics \\ Gasko M. V., PhD in Traumatology, Assoc. Professor, Department of Traumatology and Orthopedics \\ Tulyulyuk S. V., Assistant, Department of Traumatology and Orthopedics \\ Shutka V. J., MD, PhD, Assoc. Professor, Department of Urology and Neurosurgery
}

Higher State Educational Establishment of Ukraine

«Bukovinian State Medical University», Ukraine.

DOI: https://doi.org/10.31435/rsglobal_ws/31082019/6630

\section{ARTICLE INFO}

Received: 14 June 2019

Accepted: 22 August 2019

Published: 31 August 2019

\section{KEYWORDS}

osteogenesis, iodine, deficiency.

\begin{abstract}
The study presents the results of investigation of iodine deficiency condition on the bone tissue and healing post-traumatic bone defects under conditions of iodine deficiency.

The experimental part of the study was performed on 63 randomized brand albino male rats of 3-month age. Peculiarities of the reparative osteogenesis were studied on the model of a traumatic injury simulated one-type in the proximal meta-diaphysis of the femoral bone irrespective of the experimental conditions in the frontal plane in the form of perforated defect. The defect was made by means of a drill $1 \mathrm{~mm}$ in diameter.

The results of the study are indicative of a negative effect of iodine deficiency produced on reparative osteogenesis manifested by inhibition of the process and associated with disorders in the formation of osseous regeneration, deterioration of the structural-functional state of the osseous tissue, development of degenerative-necrotic changes in the osseous tissue and epiphyseal cartilage.
\end{abstract}

Citation: Kovalchuk P. Ye., Gasko M. V., Tulyulyuk S. V., Shutka V. J. (2019) Reparative Osteogenesis in Normal State and Under Conditions of Iodine Deficiency. World Science. 8(48), Vol.2. doi: 10.31435/rsglobal_ws/31082019/6630

Copyright: (C) 2019 Kovalchuk P. Ye., Gasko M. V., Tulyulyuk S. V., Shutka V. J. This is an openaccess article distributed under the terms of the Creative Commons Attribution License (CC BY). The use, distribution or reproduction in other forums is permitted, provided the original author(s) or licensor are credited and that the original publication in this journal is cited, in accordance with accepted academic practice. No use, distribution or reproduction is permitted which does not comply with these terms.

Iodine effect on the skeleton and bone regeneration is of an indirect character. Iodine plays a crucial role in the functioning of the thyroid gland hormones, and it is contained in the main hormones: triiodothyronine (T3) and thyroxin (T4), which are the essential regulators for normal development and functioning of the skeleton. Multi-aspect investigations of schoolchildren in Greece, Iran and India residing in the regions with iodine deficiency, determined retardation of growth and maturation of the osseous tissue, which positively correlated with the level of thyroid-stimulating hormone and dysfunction of the thyroid gland $[2,3,10]$.

Nowadays numerous studies evidence the effect of thyroid hormones on the development and metabolism of the skeletal tissues. Thyroid hormones are essential for a normal growth and development. Thyroid hormones in physiological concentrations are found to stimulate proliferation and activity of osteoblasts, and biosynthesis of the matric macromolecules and its formation outside of the cells, promote proliferation and maturation of chondrocytes in the epiphyseal cartilage causing the growth of bones at length $[4,5,6]$. A part of the mechanism of the thyroid hormones action is availability of nuclear receptors in the osteoblast-like cells and osteoblasts, stromal cells of the bone marrow, osteoclasts and chondrocytes of the epiphyseal cartilage [7]. 
An indirect action of the thyroid hormones is associated with their regulation of other important hormones and hormone-like substances essential for the development, growth and metabolism of the bone, such as interleukin-6 (IL-6), IGF-1, growth hormone in the blood serum T3 [8,9].

Today a number of unsolved issues remain outside the attention of researchers, and they require investigation. They are: effect of iodine deficiency condition on the osseous tissue and healing of post-traumatic bone defects under conditions of iodine deficiency.

Objective: to study in the experiment peculiarities of reparative osteogenesis in case of posttraumatic defects of meta-diaphysis of the femoral bone under conditions of iodine deficiency.

Materials and methods. The experimental part of the study was performed on 63 randomized brand albino male rats of 3-month age. Peculiarities of the reparative osteogenesis were studied on the model of a traumatic injury simulated one-type in the proximal meta-diaphysis of the femoral bone irrespective of the experimental conditions in the frontal plane in the form of perforated defect. The defect was made by means of a drill $1 \mathrm{~mm}$ in diameter.

The animals were kept under conditions according to the requirements concerning their keeping and diet.

The experiment was conducted on the control and main group of animals.

The control group included 21 animals. The course of reparative osteogenesis was studied on them without use of pharmacological or physical effect on osteogenesis itself.

The main group included 42 rats divided into two subgroups 21 animals each.

Iodine deficiency in the main group of animals was simulated by means of diet with a low content of iodine (under $6 \mathrm{mcg} / 100 \mathrm{~g}$ ) and administration of Mercazolil (Thiamazole) preventing formation of the thyroid hormones in the parathyroid gland but without producing effect on the peripheral transformation of T4 into T3, and being widely used in the treatment of the thyroid gland hyperfunction. A daily single dose of Mercazolil was introduced every day during 21 days into the stomach in the form of water-starch suspension.

21 days later a perforating defect was made in all the animals in the portion of the proximal metadiaphysis of the femoral bone. After getting the injury the first subgroup of animals was still kept under iodine deficiency conditions, and the animals from the second subgroup received diet with higher content of iodine in combination with the pharmacological agent Iodomarin in the dose of $3.73 \mathrm{mcg} / \mathrm{kg} / \mathrm{day}$.

The course of reparative osteogenesis under effect of the above induced conditions was investigated histomorphologically in the periods of 7,15 and 30 days after the defect was received.

Surgery was performed on the femur under conditions of an operating room in the vivarium of Higher State Educational Establishment of Ukraine "Bukovinian State Medical University" keeping to the rules of aseptic and antiseptic under Aminazine-Ketamine narcosis.

With the purpose to evidence iodine deficiency condition or its lack, the concentration of iodine in the urine was examined in the experimental animals by means of the set Iodtest №50.

Histologic specimens were obtained according to the common methods with hematoxylin and eosin staining techniques. Avtandilov planimetric ruler was used to measure the area of post-traumatic regeneration [1].

During the experiment the animals were kept under proper climatic conditions, keeping to 12-hour regimen of light and standard diet according to the requirements and international principles of the European Convention for the protection of vertebrate animals used for experimental and other scientific purpose: Council of Europe dated 18.03.1986. - Strasburg. - 1986. - 52 p.), the Law of Ukraine № 3447IV dated 21.02.2006 "On protection against cruelty to animals" and bioethics standards.

The material was statistically processed by means of the software Statisticav. 5.5. ShapiroWilk normality test was used to check the distribution. The hypothesis concerning statistical similarity of the two samples was checked by means of Student criterion, correlation analysis - by means of Spearman criterion.

Results. 7 days after the defect was got an active cellular proliferation was observed in the animals from the control group on the side of the periosteum and endosteum with the formation of the membrane reticulated osseous tissue against the ground of mildly manifested signs of hyperemia and swelling. The defect was filled with the newly formed osseous tissue in $31,86 \pm 1,06 \%$ (Fig. 1 a). In the animals from the first and second subgroups of the main group a network of the osseous membranes with irregular thickness was found. Intra-trabecular cells between them were filled mainly with fibroreticular bone marrow with a spread lumen of capillaries filled with blood and pronounced plasmostasis and swelling signs. The defect was filled in $19,57 \pm 0,95 \%$ and $22,36 \pm 0,82 \%$ respectively. 
15 days after the perforating defect was made in the animals from the control group microscopic examination was conducted and it determined slow formation of the periosteal osseous regeneration, which was mainly limited by the portion of diaphysis defect of the femoral bone. Endosteal reparative process was characterized by the formation of the membrane reticulated osseous tissue, and its rebuilding by filling the defect with the newly formed osseous tissue was $48,71 \pm 2,03 \%$. In animals from the first subgroup intratrabecular cells are mainly filled with fibroreticular bone marrow with a spread lumen of capillaries filled with blood and pronounced plasmostasis and swelling signs. The compact osseous tissue in the margins of the defect of the femoral bone contained spread areas of necrosis. In their periphery the layer of the osseous tissue was formed in the shape of a closing plate. The defect was filled in $23,57 \pm 0,95 \%$. The second subgroup - gradual restoration of reparative activity of the osseous tissue formation accompanied by an increased activity of proliferation and osteoblast cellular elements, the defect was filled in $29,00 \pm 0,82 \%$.

30 days after receiving the defect in the animals from the control group proliferative activity of the epiphyseal cartilage cells and the process of endochondial ossification available are indicative of a rather high activity an physiological regeneration (formation) of the osseous tissue in the process of the longitudinal growth of the bone. The defect was filled with the newly formed osseous tissue in $95,42 \pm 2,03 \%$. Certain peculiarities were observed in the animals from the first subgroup in the formation of the osseous regeneration, induced by the lack of selenium intake into the body. The changes found first of all touched upon proliferation and differentiation of cells into the osteoblasts, which are responsible for the formation of the osseous tissue. The defect was filled in $38,14 \pm 1,50 \%$. The second subgroup - reparative processes were progressing and resulted in the formation of the osseous tissue and its apposition on the surface of the bone lamellae. The intra-trabecular cells were filled with proliferating osteogenic cells. Not numerous areas of osteoclasts were found. They resorbed dystrophic and necrotic changed osseous tissue. The defect was filled in 51,28 $\pm 1,50 \%$.

The results of the study are indicative of a negative effect of iodine deficiency produced on reparative osteogenesis manifested by inhibition of the process and associated with disorders in the formation of osseous regeneration, deterioration of the structural-functional state of the osseous tissue, development of degenerative-necrotic changes in the osseous tissue and epiphyseal cartilage (Fig. 2).

Conclusions. 1. In animals from the experimental group with simulated iodine deficiency the osseous regeneration was slow and occurred against the ground of pronounced of blood supply disorders.

2. The course of reparative process in the animals from the first subgroup of the main group with simulated iodine deficiency was characterized by inhibition of the formation and remodeling of regeneration, which is reflected in the reduction of the relative area of the lamellar osseous tissue in comparison with that of the control.

\section{REFERENCES}

1. Автандилов Г.Г. Медицинская морфометрия. Руководство. - М.: Медицина, 1990. - 384 с.

2. Бруско А. Т. Теореттичні та біологічні аспекти загоєння переломів кісток / А.Т. Бруско // Хірургічне лікування, медична реабілітація, фізіотерапія переломах при переломах кісток та захворюваннях суглобів: міжнар. наук.-практ. конф. 3 міжнар. уч., 10-11 квітня, 2008 р.: тези доп. - КиївМаньківка, 2008. - С. 14-17.

3. Гайко Г. В., Бруско А. Т. Теоретические аспекты физиологической и патологической регенерации костей с позиций системных представлений // Журнал НАМН Украины. - 2013. - Том 19, № 4. - С. 471-481

4. Григоровский В. В. Метаболическая реакция организма и репаративная регенерация кости при инициированном повреждении / В.В. Григоровский, С.М. Магомедов // Ортопед. травматол. - 2000. - № 2. - С. 101-102.

5. Зміни гормонального стану при ускладненому перебігу репаративного остеосинтезу після множинних та поєднаних переломів довгих кісток / О.О. Коструб, В.О. Литовченко, М.I. Березка [та ін.] // Проблеми остеології. - 2000. - Т. 3, № 4. - С. 35-36.

6. Danish investigation on iodine intake and thyroid disease Dan Thyr: status and perspectives / P. Laurberg, T. Jorgensen, H. Perrild, L. Ovsen [et al.] // European Journal of Endrinology. - 2006.- Vol. 155. - P. $219-228$.

7. Ren F. L. Efect of selenium and iodine deficiency on bone, cartilage growth plate and chondrocyte differentiation in two generations of rats / F.L. Ren R.X. Guo //Osteoarthritis Cartilage. - 2007. - Vol. 15.- P. 1171-1177.

8. Visser T. J. The elemental impotance of ufficient iodine intake / T.J. Visser // Endocrinology. - 2006. Vol. 147, № 5. - P. 4039-4045.

9. Thyroid status during skeletal development determines adult bone structure and mineralization / K. Basset, K. Nordstrom, A. Boyde [et.al.] // Mol Endocrinology. - 2007.- Vol. 21, № 8. - P. 1893-1904.

10. Volzke H. Association Between Serum Insulin-Like Growth Factor I Levels and Thyroid Disorders in a Population-Based Study / H. Volzke // J. Of Clinical Endocrinology \& Metabolism. - 2007. - Vol. 92, № 10. - P. 4039-4045. 